\title{
MANAGING TEACHERS WORK SAFETY FOR QUALITY SERVICE DELIVERY IN SECONDARY SCHOOLS IN RIVERS STATE
}

\author{
EMMANUEL O. ESEYIN, STALLA CHIDINMA ANIEHEOBI, SARAH OYEMWEN OSAH \\ AND OLOLADE ADEBIYI
}

(Received 31, March 2017; Revision Accepted 28, June 2017)

\begin{abstract}
The paper is on teachers work safety as a roadmap to quality service delivery in secondary schools in Rivers State. The paper utilize qualitative technique method for the analysis of data. Data were sourced from secondary sources such as textbooks, journals and the internet. The concept of work safety was defined as protection from various forms of work hazard. The forms of work threat facing secondary school teachers were highlighted such as bullying, sexual harassment, deprivation of human rights etc. The implications of teacher's threat at work were identified such as absenteeism, depression, classroom disorderliness. The contributions of teachers work safety to learning in secondary schools were identified. The methods of enhancing teachers work safety in secondary schools within the state such as school plant planning, setting rules and regulations etc. were discussed. The paper concludes that teachers work safety is important for quality service delivery in secondary schools in the state. It was recommended that teachers unions should be established in secondary schools and teachers should also be educated on work safety measures in secondary schools within the state.
\end{abstract}

KEYWORDS: Safety, Secondary, Student, Service, Schools, Service Delivery

\section{INTRODUCTION}

The work environment is a place where inputs are rationally utilized for the actualization of the goals and objectives of any organization. The various inputs used in the production process must be properly utilized in order to generate an optimal output from the production process. There are various inputs that are used in the school system for the achievement of educational objectives. Lacireno-Paquet, Morgan, Mello and Ed (2014) opined that the impact of the teacher is determined by the achievement of students learning outcomes. The teacher is therefore an important input needed in the school in order to ensure that the goals and objectives of the educational system are achieved.
It is important to note that efficiency and effectiveness is important in any educational system in order to assist the teacher carry out his or her responsibilities in a professional manner. However, proper service delivery cannot be achieved from the teacher when the work environment is not safe for the teacher to carry out their various functions. The teacher needs to feel a sense of security at work before he or she can function properly in the school. Prinsloo (2005) opined that a safe school is important for effective teaching and learning. The teachers just like workers in other organizations will not be able to risk their lives and welfare for the organization and as such they require protection from harm to be able to work properly in the school.

Emmanuel O. Eseyin, Department of Educational Management, Faculty of Education, University of Port Harcourt, Rivers State, Nigeria.

Stalla Chidinma Anieheobi, Department of Educational Management, Faculty of Education, University of Port Harcourt, Rivers State, Nigeria.

Sarah Oyemwen Osah, Department of Educational Management, Faculty of Education, University of Port Harcourt, Rivers State, Nigeria.

Ololade Adebiyi, Department of Educational Management, Faculty of Education, University of Port Harcourt, Rivers State, Nigeria. 
The safety of the teacher at work is not limited to the provision of physical protection from harm. The safety of the teacher also includes his or her job security. Safety of the teacher at work also includes the availability of basic financial and non-financial resources and the safety of the teacher from danger. The safety of the teacher at work includes the protection of the teacher from physical, material and intellectual threats. The school administrators and the government therefore needs to ensure that all these basic needs are provided for the teacher to be able to confidently and conveniently carry out his or her responsibilities in the most efficient and effective manner.

\section{Concept of Work Safety}

The need for safety for better service delivery among teachers in secondary schools cannot be over emphasized. Safety at work provides confidence and boost willingness for work in any formal organization. The extent of safety in the work place determines the extent to which workers can go to ensure the achievement of the organizations goals and objectives. Masitsa (2011, p.165) stated that "to be safe is to be protected from any form of danger or harm, or to be secure". Work safety is therefore the absence of threats of danger to a workers life, property or opportunities in the process of carrying out their duties. It is also the absence of threat in the workplace in the process of pursuing the goals and objectives of the organization such as the school system.

\section{Safety Problems Confronting Secondary School Teachers at Work}

Teachers need to be safe at work for them to be able to function efficiently and effectively in the school. However there are diverse forms of job threat that prevents the teacher from working optimally in the school. Some of the forms of job threat that teachers are exposed to in the school includes but are not limited to the following:

Sexual Molestation: Teachers as well as students are exposed to various forms of sexual harassment in the school in the process of discharging their responsibilities. Students sometimes sexually harass their teachers and teachers of opposite sex also sometimes sexually harass one another. Smit and Plessis (2011) opined that sexual harassment exist when male with power and position decides to sexually harass female educators. Sexual harassment hinders the freedom of the teacher in the discharge of their duties especially to students and other individuals of the opposite sex. When a teacher is sexually harassed, he or she may not feel secured to carry out their responsibilities without adequate security. Female teachers face more of sexual harassment from male teachers and students than the other way round. This can discourage the teachers from going about their work efficiently and effectively.

Bullying Teachers: Bullying is a form of threat that teachers are exposed to in the school environment. Dahlheimer (2004:8) stated that "bullying can be manifested verbally, physically, and emotionally". There are cases in the school environment where teachers are engaged in a physical fight with either their fellow teachers or with students. When teachers are being bullied at work, it limits their freedom to move round the school and out of the school to carry out their educational responsibilities. When teachers are exposed to physical dangers, it can also hinder their ability to carry out the various physical tasks that is expected of them in the school. Bullying is a form of work threat that hinders the teacher from performing at their best in the school.

Deprivation of Rights: Masitsa (2011:167) stated that "insecurity at school may undermine the teacher's right to have his/her dignity respected and protected [and] this may have a negative impact on his or her in locus parentis status". The deprivation of basic rights within and outside the school is another form of threat at work that can limit a teacher's effectiveness at work. The teacher is supposed to enjoy basic rights in the school such as freedom of movement, freedom of association, access to information, right to fair hearing etc. However, when these rights are deprived from the teacher, the teacher can feel insecure in the workplace. The provision of basic rights at work is a necessity for the discharge of the teacher's responsibilities in the school. However, the teacher can be deprived of some of his or her fundamental rights and this can be a form of job threat which limits the teacher in performing his or her duties to the best of his or her ability.

Insubordination: There are students in different schools who are known for being law breakers and who disobey school principals and authority (Rigby, 2000). The manner in which students challenge the authority of their teachers can pose a threat to the relevance of the teacher in the 
school environment. Students sometimes challenge the authority of their teachers and in some other cases, fellow teachers challenge one another at work and the school administrators may also be involved in this dilemma. This situation hinders the ability of the teacher to command respect in the school premises which is required for the teacher to carry out his or her responsibilities at work.

\section{Implications of Unsafe Work Environment on Teachers}

Teacher's job threat in the school has diverse implications on the various educational stakeholders. The following are some of the implications of the threat of the teacher on the entire school environment:

Poor Social Life: The threat of the teacher has various consequences on the social life of the students. The teacher is expected to teach students in the school the right knowledge, skills and attitude that is required for the student to become a functional member of the society. However when the teacher feels threatened at work, he or she will not be able to transmit these qualities to the students. Similarly, the teacher is supposed to empower the students with the right technical, communication and relationship skills needed for growth and development. These values are needed for the students to relate properly with their immediate environment. However, when the teacher cannot carry out his or her duties properly, the students are deprived of this opportunity of developing a healthy social life.

Induced Depression: Teachers job threat can also result to depression on the part of the teacher. When teaching activities become stressful as a result of job threat, it can result to depression (Usman, Ahmed \& Ahmed, 2011). Teachers who are exposed to physical or emotional danger at work can be exposed to depression. Depression also affects the ability of the teacher to teach professionally. When the teacher is depressed as a result of his or her job threat, the teaching done in the classroom may not be as effective as possible. The teacher is supposed to have the right mindset when going to the classroom so that the teaching-learning process can be meaningful. However, these objectives may not be adequately achieved when the teacher is emotionally disturbed as a result of the level of threat attached to his or her responsibilities in the school.
Classroom Disorderliness: Bogdan and Biklen (2004) noted that it is the responsibility of every teacher to ensure order and security in their various classrooms. Classroom management is very important for the educational success of any school. The management of the classroom determines whether teaching and learning in the school will be meaningful or not. When the teacher's job is not safe, he or she may not be in total control of the school. Students will be left to manage themselves when the teacher's job is insecure. The safety of the students in the classroom is positively related to the safety of the teacher. The teacher who is the manager of the classroom must have job security before he or she can protect the other members of the classroom.

Frequent Absenteeism: Teachers are exposed to different form of job accidents and injuries which limits their presence at work (National Employers' Organisation for School Teachers (2000). Teacher's attendance at work can be lowered when job safety is low. The teacher can decide to stay away from work when he or she feels that the job does not guarantee his or her safety. Job threat in the school does not only reduce the attendance of teachers in the school but also reduces the student's attendance rate. When the school is not safe for the teacher, the level of absenteeism from work is expected to increase. The various physical, emotional, material and financial threats that teachers face in school can hinder them from coming to school.

Human Rights Violation: The level of job threat at work is also a form of human right violation which teachers face at work. Job threat at work can come in the form of financial deprivation, unavailability of teaching resources and other safety implements. This situation can hinder the teacher from enjoying other basic rights that he or she is expected to enjoy at work. The level of threat at work can therefore result to the deprivation of the rights of the teacher which is required for him or her to discharge his or her responsibilities appropriately.

\footnotetext{
How Teachers Job Safety Contributes to Secondary Schools Performance

The need for teacher's job safety cannot be over emphasized. When the teachers are safe at work, it has various benefits on all educational stakeholders. The benefits of teachers job safety on students in secondary schools includes but is not limited to the following:
} 
Improved Classroom Management: The safety of the teacher at work positively affects the condition of learning in the classroom. Teacher's job safety determines the safety of the classroom for learning. Nakpodia (2010) noted that the teachers are problem solving agents in school and this is guaranteed when the teacher is also safe in the school environment. When the teacher is exposed to any form of danger or threat at work, it can also affect the safety of the students. The teacher whose job is protected is however in a better condition to organize the classroom for improved learning. Teacher's job safety helps the teacher to better organize the classroom which affects the safety of the students in the classroom and the school at large.

Higher Academic Success: The teacher is an important educational resource that affects learning among the students. The teacher and his style of teaching can determine whether students will perform well or not at any level of education (Musau \& Abere, 2015). Student's academic achievement is expected to increase when the job of the teacher is secured. The teacher who is protected from any form of danger in the school is in the right position to assist the students to learn meaningfully. The academic success of the students therefore hinges on how well the teacher is protected from any form of internal or external threat around the school environment.

Improved Social Relationships: Teachers job safety has been identified as a very important mechanism in the enhancement of the social relationship among various educational stakeholders. The teacher serves as a link among the various educational stakeholders. Teachers serve as a connection among the students, parents and school administrators (Fritz, 2006). He or she is therefore expected to transmit the right societal values to the students and relate the needs of the students to the parents and school administrators. The teacher therefore helps to balance the social needs of the school community. This can however be hindered when the job of the teacher is not properly protected.

Safe School Environment: The teacher is responsible for correcting misbehaving students so as to make the school environment safe for other school users (Chianu, 2007). One of the responsibilities of the teacher is to ensure the safety of the school for all students, parents and other school users. The teacher helps to monitor the strengths and weaknesses of the school and proffer solutions to the challenges confronting the school. This helps to make the school environment safe for all stakeholders. However, if the teacher's job is insecure, the teacher may not be able to proffer reasonable solutions to the problems of the school for other school users. The teacher is therefore better informed to ensure the safety of the school environment for all educational stakeholders but this can only be guaranteed when the teacher himself or herself is safe from any form of threat or danger while at work.

\section{How to Ensure Teachers Work Safety for Better Performance in Secondary Schools}

Teacher's job safety is important for various reasons in the school. However, there is need for measures to be put in place for the safety of the teacher at work. The following are some of the measures that can be put in place to ensure the protection of the teacher at work:

School Plant Planning: Plant planning is very important in the protection of teachers in the school environment. The manner in which plants are planned in the school contributes to the level of teacher safety in the school. It is important that in the process of plant planning within the school, the facilities and equipment that can pose danger to the teacher in the course of the discharge of his or her duties should be kept away from the teaching and learning environment. Masitsa (2011) noted that schools safety measures should include demarcation of the school to keep strangers out of bounds and fencing of appropriate places. Similarly, educational resources that can affect the safety of the teacher should be properly secured or protected in order to limit the exposure of the teacher to occupational hazards. Teachers who have record of physical or medical abnormalities can be protected from work hazard when educational resources such as school plants in the school are properly planned.

Setting Rules and Regulations: The rules and regulations made in the school guides the activities of the students and other educational stakeholders. Rules and regulations are important in the work place as it specifies the rights and obligations of all stakeholders. When students and teachers are properly informed on the rules and regulations guiding the school, the 
teacher can be protected from various forms of threats and harassments in the discharge of their responsibilities. Rules and regulations help all individuals to know the policies guiding the activities of all individuals within the school environment and this can help protect the teacher from occupational threats.

Enforcing Disciplinary Measures: It is important that adequate disciplinary measures should be set in place in the school to prevent activities that hinder the job safety of the teacher. When teachers and students are aware of the disciplinary measures put in place to protect the job of the teacher, students and other teachers can better avoid actions and activities that can pose a threat to the teacher in the discharge of their duties. Masitsa (2011:172) stated that "the members of the school governing body should use the power granted to them by legislation to ensure school safety". Disciplinary measures also help to prevent a re-occurrence of activities that makes the teaching profession unsafe for the teacher.

Clear Hierarchy and Authorization: Organizational structure in the school is very important for all individuals in the organization for all individuals to know where their rights and obligations start and stops. Hierarchy and authority in the school is very important as it helps the teacher to be in charge on any activity committed into his or her hand. When the hierarchy of the school is properly defined and the authority of the teacher is clearly stated, it helps the teacher to be able to exercise authority on students and other subordinates. However, when the position and authority of the teachers are not properly defined, the teacher lacks the ability to exercise authority even in his or her jurisdiction and this can make his or her job unsafe for him or her as the teacher could be exposed to any form of attack.

Teacher Education: The education of the teacher is another important way of protecting the teacher from danger in the place of work. Teacher education deals with the transmission of the right values and skills into the teacher which will enable him or her to relate properly with other individuals in the school. Masitsa (2011) pointed out that it is important that regular meetings which will emphasize school safety measures should be organized between the police and other educational stakeholders such as the teacher. When the teachers are properly educated and oriented on the principles guiding their profession, it will help them to avoid activities that can expose them to danger in the course of carrying out their responsibilities. Teacher education is therefore vital for empowering the teacher with the knowledge needed to protect themselves while at work and to ensure safety in the course of doing their job.

\section{CONCLUSION}

The safety of the teacher at work is an important factor that determines how well the teacher will be able to carry out his or her responsibilities in the school. The teacher needs to feel a sense of security before he or she will be able to contribute to the success of the school system. Work safety includes providing all the necessary facilities and equipment that will enable the teacher to feel protected at work and free to contribute to the success of the school. The safety of the teacher at work is important for the teacher to be able to contribute freely to the goals and objectives of the school. This is important for the school to succeed since the teacher is an indispensable resource in the administration of any school system.

\section{RECOMMENDATIONS}

The following recommendations are made on teachers work safety for better service delivery in the school system based on the literatures reviewed:

1. It is important that teachers union should be established and should be very active in any education system. Teachers unions exist to protect the interest of the teacher in any school system. These unions should also be empowered to intervene in any cases that pose as a danger to the safety of the teacher. This is needed for the teacher to be able to carry out his or her responsibilities both efficiently and effectively.

2. The teacher needs to be trained on work safety ethics. There are diverse work safety ethics that the teacher needs to know such as a healthy interpersonal relationship with the school community. The teacher needs to be informed and trained on how to be security conscious in their work environment. This training will help the teacher to avoid situations that pose as a danger to the teacher and also how to negotiate and avoid harm 
when danger arises in the dispensation of his or her responsibilities.

3. The safety of the teacher is not limited to physical harm alone but also includes anything that stands as a threat to the emotional and material well-being of the teacher. It is therefore important that the government and school administrators should provide all the needed policies and resources that will guarantee the safety of the teacher at work. The government should make safety policies that protect the teacher at work and also provide other resources needed for the teacher to feel secured at work while the school administrators should ensure that these policies and programmes are properly implemented.

\section{REFERENCES}

Bogdan, R. C \& Biklen, S. K., 2004. Qualitative research for education: An introduction to theory and methods. Boston: Allyn and Bacon

Chianu, E., 2001. Corporal punishment in primary and secondary schools: The legal position. Asaba: Pulishers Endless Book

Dahlheimer, J. M., 2004. Teachers' perceptions of bullying behavior. Retrieved from https://core.ac.uk/download/files/214/506 6483.pdf

Fritz, G. K., 2006. Creating a safe, caring and respectful environment at home and in school. Brown University: Wiley Company

Lacireno-Paquet, N., Morgan, C., Mello, D and

Ed, W., 2014. How states use student learning objectives in teacher evaluation systems: A review of state websites. Retrieved from https://ies.ed.gov/ncee/edlabs/regio ns/northeast/pdf/REL 2014013.pdf
Masitsa, M. G., 2011. Exploring safety in township secondary schools in the Free State province: South African Journal of Education, 31, 163-174

Musau, L. M and Abere, M. J., 2015. Teacher qualification and students' academic performance in science mathematics and technology subjects in Kenya. International Journal of Educational Administration and Policy Studies, 7, (3): 83-89.

Nakpodia, E. D., 2010. Teachers' disciplinary approaches to students' discipline problems in Nigerian secondary schools: International NGO Journal, 5, (6): 144151.

National Employers' Organisation for School Teachers., 2000. Conditions of service for school teachers in England and Wale. Retrieved from https://www.teachers.org.uk/sites/de fault/files2014/burgundy-book.pdf

Prinsloo, I. J., 2005. How safe are South African schools. South African Journal of Education, 25, 5-10

Rigby, K., 2000. Bullying in schools and what to do about it. London: Jessica Kingsley

Smit, D and Plessis, V., 2011. Sexual harassment in the education sector.PER/PELJ, (14)6, 173-217

Usman, A., Ahmed, Z and Ahmed, I., 2011. Work stress experienced by the teaching staff of University of the Punjab, Pakistan: Antecedents and consequences. International Journal of Business and Social Science, 2, (8): 202-210. 